This is a pre-print version of an article published in British Politics. Please cite: Hoctor, T. (2020) 'Coming to terms with the market: accounts of neoliberal failure and rehabilitation on the British Right', British Politics 0(0) https://doi.org/10.1057/s41293-020-00141-9

\title{
Coming to terms with the market: accounts of neoliberal failure and rehabilitation on the British Right
}

\begin{abstract}
Critique of "neoliberalism" is generally thought of as a preoccupation of the political Left. Here it will be argued that the British Right has also been developing a distinctive critique of neoliberalism and its failure, whether they thought about it in these precise terms or not. This represented an attempt by Conservative intellectuals to grapple with the enduring legacy of Thatcherism in the party. The objectives of this paper are threefold. Firstly, it will examine the contours of a distinctively Conservative description of neoliberal society by drawing on the work of Jesse Norman. Secondly, it will explain and contextualise their account of neoliberal economic failure and a possible avenue to its rehabilitation. And, thirdly, it will explain why this rehabilitation was itself a failure through a critique of Norman's attempts to read Hayek through Burke. It concludes by observing that what civic forms of conservatism fail to offer is a thoroughgoing examination of functions that markets are unable to perform.
\end{abstract}

Keywords: Conservatism; neoliberalism; Big Society; Red Toryism

\section{Introduction}

Critique of neoliberalism is generally associated with the political Left. Mitchell Dean (2014) notes that neoliberalism has even been described as a 'secret handshake' between leftists. Whether the neoliberal moment has passed, is entering a new phase, or is simply so embedded that its logic transcends any specific crisis of neoliberal ideas (Peck, 2010), it is worth noting that the perception of neoliberal failure is not limited merely to the Left, but is also increasingly current on the Right and is even articulated in these terms. 
It would be easy to dismiss these accounts of neoliberal failure as the pursuit of fringe Tory intellectuals - principally David Willetts, Jesse Norman, Philip Blond and, to a lesser extent, Robert Halfon. However, dismissing the ideas underpinning the Big Society and Red Toryism would be a mistake: accounts of what I have termed neoliberal failure are increasingly gaining traction and have influenced policymaking in different factions of the Conservative Party, even against the backdrop of Brexit.

The Big Society was an attempt to grapple with the intellectual and political challenges facing a Conservative Party which had been profoundly shaped by the legacy of Margaret Thatcher and Thatcherism, but which struggled to move beyond what Gamble (2015) describes as the 'Thatcher myth'. The context of a factional division between neo-Thatcherite Conservatives and a more moderate modernising wing of the party is essential context to the political and material consequences of the Big Society. As a result, this agenda has been understood variously as a departure from and a retention of the core ideas of neoliberalism as practised under Margaret Thatcher and Tony Blair (Levitas, 2012; Sage, 2012; Corbett and Walker, 2013; Dowling and Harvie, 2014). Much debate has therefore revolved around the extent to which programmatic changes have accompanied these shifts towards communitarian rhetoric and whether such rhetoric should be considered a 'fig-leaf for neoliberalism' or a well-meant, but ill-fated desire for a concrete departure from neoliberal social policy agendas (Corbett and Walker, 2013).

This split between the neo-Thatcherite tendency and 'detoxification' or modernisation agendas represents a significant battle over the future of the Conservative Party. The argument that will be made here is that this split can be observed not only in the internal politics and policy agendas of the Cameron government but within the intellectual project of the Big Society. Jessop (2015) argues that the long-term implications of Thatcherism and its successor governments has been the creation of a new kind of highly financialised and unequal economy. There is very significant evidence that this has been the case and no account of coalition policy or modernisation can avoid the implications of austerity (Driver, 2011; Gamble, 2012; Kerr and Hayton, 2015; Smith and Jones, 2015). 
The argument of this article will be that these competing agendas are not only to be found in internal party politics and successive Conservative-led social platforms but also embedded within the Big Society itself. There is a certain irony to the fact that an intellectual project designed to reject Thatcherism introduced arguments which meant that it could not escape Thatcher's legacy to the Conservative Party. The most important expression of this, it will be argued, was an attempt to reconcile the Hayekian market with the 'little platoons' of Edmund Burke. There have also been concrete expressions of this failure to break with Thatcherism, not least in the creation of Big Society Capital which further extends the market into the sphere of social reproduction, which historically had been the sphere of the welfare state and collective organisation (Dowling and Harvie, 2014; Harvie, 2019).

Nonetheless, there is a clear impulse in the Big Society literature to reject certain aspects of deregulatory policy agendas and to provide a critique of neoliberal economic and social policy. Intellectually, scholarship produced by Jesse Norman and Philip Blond can be understood as producing an account of the failure of neoliberalism as well as attempting to provide a path towards its rehabilitation. This objective has been reflected rhetorically in Conservative Party electioneering. The Conservative Manifesto (2017, p. 9), for example, claimed that:

We do not believe in untrammelled free markets. We reject the cult of selfish individualism. We abhor social division, injustice, unfairness and inequality ...

[t]rue Conservatism means a commitment to country and community; a belief not just in society but in the good that government can do; a respect for the local and national institutions that bind us together ....

Similar claims about a civic agenda were made in the most recent Conservative Manifesto (2019) with its talk of 'levelling up'.

This article will focus primarily on ideas produced in the (milieu surrounding the) Conservative Party in the aftermath of the 2008 financial crisis through a close reading of the work of Jesse Norman. It will not focus on the disjunctures between rhetorical and programmatic aspects of the Big Society and Red Toryism, but at the specific theoretical means by which they responded to the necessity of providing a coherent account of the 2008 financial crisis and the inability of classically neoliberal thinking to deal adequately with the systemic and 
ideological challenges which it generated. In other words, to what extent has a distinctively formulated critique of neoliberalism emerged on the political centre-right and how has it critiqued and rehabilitated neoliberal ideas?

The basic objectives of this paper are threefold. Firstly, it will examine the contours of a distinctively Conservative description of neoliberal society by drawing on the work of Jesse Norman. Secondly, it will explain and contextualise their account of neoliberal economic failure and a possible avenue to its rehabilitation. And, thirdly, it will explain why this rehabilitation is itself a failure through a critique of Norman's attempts to read Hayek through Burke.

\section{The politics of the Big Society}

Scholars have measured the goals and success of the Big Society in several ways. It has been seen as (1) a principally rhetorical attempt to justify a neoliberalising agenda (North, 2011; Tam, 2011; Byrne, Foster and Kerr, 2012; Corbett and Walker, 2013); (2) a relatively wellintentioned programme which lacked the political capital to succeed within and without the Conservative Party (Sage, 2012; Heppell, 2013; Kerr and Hayton, 2015; Hayton, 2016); (3) an attempt to emulate New Labour's 'Third Way' modernisation programme (Levitas, 2012; Dommett, 2015); and (4) a semi-coherent policy platform which has had material social effects (Dowling and Harvie, 2014; Lister, 2015; Harvie, 2019).

In almost all cases, scholars point out the political and electoral necessity of rejecting certain aspects of the Thatcherite programme in response to the changing social values of the wider population. The starting point for this reorientation was Thatcher's (in)famous comment that 'there is no such thing as society', a statement dissected and rejected by David Cameron (2005), who asserted that 'there is such a thing as society, it's just not the same thing as the state'. Most also note that moving the Conservative Party away from its neo-Thatcherite agenda was both the principal aim of this project and perhaps its least successful aspect (Dorey and Garnett, 2012; Gamble, 2015). Moreover, the wider post-Thatcherite context is significant to the development of the Big Society. The changes which the Thatcher and Major governments and their New Labour successors affected in Britain's economy made a revival of civic participation in welfare provision unlikely to say the least (Levitas, 2012; Jessop, 2015). 
There had already been Conservative political programmes which, in a number of important respects, resembled the ideas which would become the Big Society. Dorey and Garnett (2012) provide a useful summary of these projects dating back to the late 1980s. Key figures in the party, including Douglas Hurd, David Willetts and Oliver Letwin had, to greater or lesser degrees, already set out projects which suggested the kind of Burkean or European Christian Democratic ideas which would inform the Big Society. These programmes were concerned to reconcile traditional conservatism with free markets as a means of carving out a greater role for civil society (Hickson 2009).

However, several factors combined to make it more likely that the Big Society would gain traction under David Cameron. Firstly, and perhaps most importantly, successive defeats on a Thatcherite platform provided the space for an alternative approach to electoral politics, if not necessarily to other questions, especially economic ones. Secondly, Cameron's leadership pitch to the Conservative Party was based upon a triangulating approach to social issues, giving him a significant mandate within the party to pursue a 'detoxification' strategy (Heppell, 2014). Thirdly, Cameron assuaged the Thatcherite wing of the party by making a series of concessions in other areas, notably on Conservative membership of the European People's Party in the European Parliament and the marriage tax allowance. The former would have proven to be a serious hostage to fortune by the early 2010s, but was expedient in 2005 .

The context to the Big Society was altered significantly by the 2008 financial crisis. Indeed, in some ways, the credit crunch led to the re-articulation of the programme which would become the Big Society in terms which also included a more thoroughgoing critique of 'neoliberal failure'. This is particularly evident in Norman's (2008) Compassionate Economics, but also in his later Big Society (2010) and Philip Blond's (2010) Red Tory, which brought together an existing critique of the state and social breakdown with an account of the economic model which had led to the 2008 crash.

The Big Society, then, responded to key imperatives for the Conservative leadership, both in terms of party management and presenting a wider narrative of the role of the state in society and the economy. Accordingly, as discussed above, scholars have looked in significant detail 
both at its role in the Conservative Party and its reception in wider society. The Big Society is widely considered to have been a failure in both regards and its failure is usually located in the party's rejection of the programme or its lack of wider success as a narrative or policy agenda (Coote, 2011; Byrne, Foster and Kerr, 2012; Kerr and Hayton, 2015). Moreover, the wider picture of social decline, shaped by three decades of stop-start austerity, is also critical to its perceived failure. Gibson $(2015$, p. 48$)$ summarises this nicely when he points out that: 'while Blond flagged up the problem, in practice the Big Society failed to account adequately for its decline and for the impact deregulated markets have upon the social fabric'.

Most analysis of the Big Society therefore understands the project as an empirical failure: of party management and social, political and economic practices. Though I do not disagree with this assessment, here, I will make a slightly different argument, claiming that this failure is not simply an empirical one, but that the theories which informed the Big Society are fundamentally incompatible with one another. In fact, the reasons for the lack of success of the Big Society project are located as much in its theoretical understanding of markets as in its practice as a political or policy programme.

To demonstrate this point I will look in depth at the work of Jesse Norman (in places supplemented by the ideas of Philip Blond). This also adds a close reading of the work of Norman to a body of scholarship which has tended to focus on David Cameron's speeches and the work of Blond as emblematic of the ideas of the Big Society, while engaging less substantially with the longer, more detailed and, arguably, more sophisticated works of Norman. In the next sections, I will argue that the Big Society contains an 'account of neoliberal failure' which argued in favour of more solidaristic, communitarian politics. However, there was also an impulse to rehabilitate neoliberal ideas through a reconciliation of the ideas of Burke about 'little platoons' with Hayekian market theory. This attempt at rehabilitation, it will be argued, was a theoretical failure because it could not adequately bring together contemporary ideas about the functioning of markets with a proto-capitalist conservative tradition emphasising the importance of institutions and tradition. 


\section{'A three-way relation between individuals, institutions and the state': society according to conservative thinkers}

The key anxieties with which Norman and Blond were preoccupied included traditional shibboleths of the Right: family breakdown, substance misuse, crime and anti-social behaviour (Norman and Ganesh, 2006, p. 2). This seemed to reflect a growing sense that it was the institutions of the pre-Thatcher era which had been key to producing some of the effects which law and order-orientated conservatives typically associated with the police and the courts. This was mixed with a disquiet about the implications of liberal individualism for the health of communities and a rejection of state-led social policy as an adequate substitute. Notably, these concerns have not been limited to the moderate wing of the Conservative Party: Norman Tebbit was recently quoted as questioning 'whether our economic reforms led to an individualism in other values in ways we didn't anticipate' (Beckett, 2019). The Big Society and Red Toryism were, then, both presaged on a critique of the libertarian and statist tendencies in economics and social policy.

To escape these two traditions, the Big Society conceptualized 'a three-way relation between individuals, institutions and the state' (Norman and Ganesh, 2006, p. 47). This represented a more significant rupture with Conservative thinking in the previous thirty years than it might appear. Free market thought had tended to oppose the interests of the individual and the state and critiqued the public sector on this basis. ${ }^{1}$ Norman took as his starting point a rejection of Margaret Thatcher's (in)famous remark that 'there is no such thing as society'. He noted that this ignored a significant portion of the conservative intellectual tradition, which he identified as split between paternalist and libertarian tendencies. The primary thinkers of the former tradition were, he argued, Edmund Burke and Michael Oakeshott, while the latter was exemplified by Friedrich Hayek.

In contrast to the Third Way, which de-emphasized collectivism in favour of politics conducted at the level of the individual, the Big Society was concerned to reintroduce a conceptual

\footnotetext{
${ }^{1}$ This was itself a significant departure from classical liberalism: Mill was just as concerned with the 'tyranny of the majority' as state oppression and saw a clear role for the state in protecting minorities, such as religious non-conformists.
} 
sphere for civil society. Blond, for example, claimed that '[T]he very idea of working with others to represent our collective interests or challenge some political decision is almost unthinkable' and that '[a]utonomous working-class social institutions arose and gave birth to health-insurance schemes, mutual-aid societies and the trade unions' (Blond, 2010, pp. 7, 14). A similar idea emerged in the Labour Party at around the same time under the guise of Maurice Glasman’s ‘Blue Labour' (Sage, 2012).

From their choice of institutions, Norman and Blond implicitly saw this as primarily a workingclass issue and were concerned with the decline of what they called 'working-class social institutions', including friendly societies, mutuals and trade unions (on which subject see also Halfon, 2012). Norman's criticism of this was chiefly aimed at 'Fabianism' (i.e. the modern Labour Party and Blairism), but he mutedly acknowledged the impact of the Thatcher era on working class organization. Indeed, the difficulty Norman faced in criticising Thatcher means that in places his work virtually reaches the level of esoteric writing in the Straussian sense (Strauss, 1988).

Blond, who was not operating in the constrained environment of the Parliamentary Conservative Party was much less reserved, arguing that Margaret Thatcher:

threw the baby out with the bathwater by completely surrendering the entirety of British public life and its related values to the dictates of a neoliberalism whose consequences she would not have supported and the operations of which she clearly did not understand (Blond, 2010, p. 18).

Norman claimed that this turn against society in favour of markets ignored the paternalist portion of the conservative tradition. To remedy this, he put forth a thoroughgoing explanation of the role of institutions in the triad of individual, institution and state mentioned above. Institutions, such as NGOs, mutuals, local parishes, the Women's Institute and so on, could organize and deliver public services in place of the state or the private sector. The 'monopoly form: that of the shareholder corporation' was also critiqued, with Norman arguing that this narrowing of institutional forms was neither as efficient as generally claimed, nor particularly desirable, since it disempowered service users. This was aimed at the New 
Public Management structures introduced by Labour as much as a criticism of Conservative policy from the late 1980s and 1990s (Norman, 2008, p. 76).

For Blond, the key economic 'institution' which should be focused on was the firm, noting that this is well established in economics making "the fashion for "neo-liberalism" among politicians rather outdated' (Blond, 2010, p. 195). Norman's most important point for present purposes is similar but more technical and original. The theory of institutions which informed the Big Society owed a very clear debt to Burke but extended the logic of Burkean institutions significantly. Writes Norman:

we should not restrict ourselves to the little platoons. the regiment and the brigade are no less important, so to speak. And we should not even at this stage exclude institutions that have no physical presence at all. So we are talking not merely about a particular local church or rugby club or branch of the Women's Institute; but also about the market, the nation state and the city; and more abstractly still, about the family, marriage, and the rule of law (Norman and Ganesh, 2006, p. 46; Norman, 2010, p. 106).

Norman's inclusion of 'abstract' institutions, especially the market, will form the basis of the discussion below. However, it is worth observing that it resembles articulations of Swedish social democracy in several important respects (See e.g. Kielos, 2009).

\section{'Rigor Mortis economics' and the financial crisis}

The Big Society had asserted specific notions about the place of the individual, civil society and the state, but it was also faced with one of the most serious challenges to those assumptions since the 1970s: the 2008 financial crisis. Norman aimed to resolve this by introducing a hard distinction between Friedrich Hayek and other free market economists, notably Milton Friedman and the public choice theorists, generally associated with neoliberalism.

To achieve this split, Norman established Milton Friedman and public choice theorists, such as James Buchanan, as supporters of the homo economicus model of economic decisionmaking and then set about refuting it. Homo Economicus, he argued, was alien to the earliest 
tradition of economics, claiming that Adam Smith should be understood as much as a moral philosopher as an advocate of market economics. Rather than the progenitor of a discipline based on rationalist assumptions and mathematical modelling, Smith (and to a lesser extent John Stuart Mill) should be seen as the father(s) of a tradition preoccupied with markets because of their inherent capacity to create a good society. This not only set out the contours of his account of neoliberal failure but also laid the ground work for the rehabilitation of liberal economics, since it was to the good society of Smith and Mill which the Big Society hoped to return through Burke and Hayek.

Homo Economicus, it was claimed, actively mitigated against civic virtue by reducing individuals to an idealized model based on their aggregate choices in markets. This criticism of public choice theory is pertinent. Consider Buchanan and Tullock's assertion that the distributive logic of markets means that 'no specific assumptions concerning the extent of equality or inequality in the external characteristics of individuals in the social group' are necessary (Buchanan and Tullock, 1999, p. 19). But Norman goes further in his criticism of public choice theory and the Chicago School. Their theories, he stated, removed properly political spheres of activity in favour of a focus on economics and markets. He writes:

Thus was politics logically subordinated to economics, and the theoretical justification laid for centuries of voter disgust, before and afterwards, with politicians and public servants (Norman, 2008, p. 26, 2010, pp. 55-56).

Through this means, Norman created a hard distinction between the Chicago School and public choice theory and the work of Hayek, laying the foundation for his attempt to reconcile institutions with the market. He provided a succinct summary of the train of this argument, stating:

Present-day conservatives will be closer to Hayek when he said that the whole nature and character of individuals is determined by their existence in society. Markets are then seen for what they are: not as ends in themselves, but as limited and constrained means - albeit the greatest means yet devised - to generate wealth and prosperity, and as having the inherent capacity to 
promote freedom and so to challenge bureaucratic authority (Norman, 2010, p. 184).

And Blond agreed, arguing that:

What we have at present, after thirty years of letting the markets rip, would not be recognised even by the great liberal conservative economist Friedrich Hayek as a free economy - it is Milton Friedman's bastard laissez-faire inversion of it, in which power and wealth flow upwards to the centralisers of capital (Blond, 2010, pp. 33-34).

In other words, there is no such thing as homo economicus, only individuals conditioned by their place within society. This offers a logical starting point to begin reconciling the thought of Hayek with Burkean institutions.

The Big Society's account of the financial crisis is posited in similar terms. What the financial crisis revealed, it was suggested, was that the 'standard economic model', understood as public choice theory arguments about the rationality of human behaviour, was false. Not only do individuals not act rationally, but the aggregate of human choices also fails to conform to this model. Financial markets and experienced investors are prone to following fads, becoming obsessed with irrelevant detail and engaging in short-term thinking. Moreover, markets are not inherently rational with mispricing occurring as a result of these fads and fashions.

Norman also associated the homo economicus position of 'rigor mortis economics' with New Labour. He cited various examples of Blair-era policies which had been shaped by this kind of logic, with a focus on tax credits, while associating this turn (not unreasonably) with the centralization of British politics and the increasing costs of consultancy and modish 'lean management' techniques in public services. The Big Society therefore rejected the logic of central targets, 'inspection and compliance regimes' and quantification in public services in general (Norman, 2010, p. 72). Moreover, Norman linked this back to his questioning of the shareholder corporation as the default form for all kinds of organization, especially in the 
public sector, creating the stepping stone for his reintroduction of the institution as a major actor in public services.

There is, though, a certain inconsistency to all of this. Norman's criticisms of market irrationality and New Labour's management of public services make sense, but not if the end goal is to reopen space for Hayekian market theory. Even though, as will be discussed in more detail below, Hayek makes fewer assumptions about individual behaviour in markets than public choice theory, Norman's critique of mispricing and quantification is as relevant to Hayek as to Friedman and Buchanan and Tullock. Hayek's conception of price is a crude solution to a complex problem. The problematic of price in Hayek operates at both ontological and epistemological levels. Hayek posits 'ontological uncertainty' in which it is impossible for any single actor to fully comprehend price signals in toto. This creates an associated epistemological notion of knowledge as inherently incomplete (Bronk, 2013). Hayek's notion of price, however, avoids this question in practice, by asserting price signals as an ontological category, obfuscating complex questions about value and the nature of knowledge raised by his own arguments. Prices in markets become immutable and given, despite the posited complexity of their social origin, rendering the background to the creation of a price irrelevant once the price signal enters the market.

Moreover, some of the policy positions put forward by Norman and his fellow travellers of the late 2000 s conform poorly to their own critique. The Conservatives' flagship Free Schools policy, for example, was based on a policy borrowed from Sweden which was explicit in its deployment of Friedmanite economics (Exley and Ball, 2011). This substantiates the claim, made forcefully by Corbett and Walker (2012), that the Big Society entailed limited practical change of direction in the functioning of the UK's social policy framework or the structure of Britain's accumulation regimes.

These objections notwithstanding, the Big Society did set up the chief contours of a distinctively conservative account of neoliberal failure - shared by other thinkers like Philip Blond - as well as the path to a rehabilitation of a free market economic system. Norman provided a distinctive (at least on the Right) critique of the Chicago School and public choice theory to account for the neoliberal failure of 2008. In doing this, he also provides a pathway 
for the rehabilitation of free market economics to be found in the work of Hayek. This will be explored in the next section.

\section{Neoliberal relapse: The failure to read Hayek through Burke}

The discussion so far has set out what has been termed an account of neoliberal failure using the work of Jesse Norman and to a lesser extent Philip Blond. Norman's critique of the Chicago School and public choice theory centred heavily on their notion of the rational economic subject and the domination of the shareholder company as an institutional form. These critiques led to a rehabilitative movement which sought to reject certain notions of the market and reclaim others as part of a programme for the reform of capitalism and public services. This section will examine why attempts to rehabilitate neoliberal economic arguments through cross-pollination with the thought of Edmund Burke were a failure. It will do this by first elaborating Norman's attitudes towards Hayekian markets and institutions and then pointing to the significant theoretical difficulties in bringing together two political philosophies with radically different social ontologies.

The core issue faced by proponents of the Big Society was to integrate the functioning of the market within a political project that was so heavily focused on expanding the role of civil society. This was by no means a straightforward problem. As noted above, Norman had offered a tripartite model of society (individual-institution-state) and set out a forceful critique of public choice theorists and associated the work of Friedman and Buchanan and Tullock with a perceived culture of materialism in Britain that had contributed to the 2008 financial crisis, that is to say, with the failure of neoliberalism as a governing programme. This allowed him to retain Hayekian theory as a framework for social interaction because of its lack of specific assumptions about the nature of the individual actor in a market.

This presented a route to a rehabilitation of neoliberal economics and conservative thought more generally by reconciling institutions and markets. It was also more thoroughgoing than Blond's response to this question, which focused on the firm, something Norman had already rejected as undesirable, at least as a 'monopoly form'. However, it is precisely the comprehensive nature of this re-reading of conservative thought that leads to its failure to escape the problem of neoliberal philosophies of the market and the Thatcherite political 
legacy which is its British context. It is not possible to reconcile contingent institutions with transcendental notions of the market. The rest of this section will justify this claim.

Although Hayek did produce economic work in the traditional sense, it is his output as a political theorist which is more conventionally read today. This is revealing, since very little of Hayek's work on economics as such is considered of value and his political and epistemological concepts are often supplemented with other forms of price theory if they are to be applied (Peck, 2010). Perhaps Hayek's most important contribution to modern economic theory is 'catallaxy' (Hayek, 1945, 2013), the idea that spontaneous order emerges from the chaos of market signals. Hayek's market is conditioned by the impossibility of any single individual possessing the capacity to understand the multiplicity of economic decisions in a complex society. However, he immediately reintroduces the possibility of a rationally ordered society by arguing that:

The mere fact that there is one price for any commodity ... brings about the solution which (it is just conceptually possible) might have been arrived by one single mind possessing all the information which is in fact dispersed among all the people involved in the process (Hayek, 1945, p. 526).

This line of argument is primarily aimed at economic planning, since even the most sophisticated planners would be unable to comprehend and aggregate the vast numbers of price signals generated in a modern capitalist society. However, despite the implied rejection of the capacity of individuals to produce rational economic outcomes, for Hayek, the sum of market decisions is effectively analogous to the thickest understanding of Reason, in which Reason presents the possibility of an ordered society through rational argument.

Recent scholarship on Hayek has emphasised the providential nature of his thought, linking catallactics to the theological work of the Scottish moralists (Cornelissen, 2017; Whyte, 2019). Whether understood as a secularised religious concept or a form of Reason, his position is analogous with the Christian union of society through the Word of God, as in John 1:1. ${ }^{2}$ In Hayek's schema it is individual price signals which complete the Word, arbitrated by the

\footnotetext{
2 'in the beginning was the Word / and the Word was with God / and the Word was God'
} 
market, even though the mass of these signals is incomprehensible to individual actors in markets.

In contrast to Chicago School economists, notably Friedman, and public choice theorists, like James Buchanan, of whom Norman had been critical, Hayekian market theory appeared to present the possibility of reconciling a rejection of homo economicus with the potential for a spontaneously ordered society through the market. Moreover, the abolition of economically rational man presented an opportunity to reconcile contemporary capitalist markets with the irrational subject of Burke and traditional conservatism, thereby making civic conservatism consistent with ideas about free markets traditionally associated with the neo-Thatcherite wing of the Conservative Party.

Following Burke, Norman had strongly rejected any attempt to embed rationality in the subject, as is found in public choice theory, rejecting homo economicus, but in his use of Hayek he simply moved the capacity for generating a rational totality from the subject to the object. Instead of a rational individual making perfect choices in a facilitating market, the site of rationality is moved from the individual to the market itself. There are serious implications for the coherence of public choice theory if people do not behave rationally (as they did not in the lead up to the financial crisis, for instance), but in Hayek's system this is irrelevant, at least in Norman's reading, since the market can aggregate even imperfect economic decisions. The market therefore keeps open the potential for a rationally ordered society even if people behave irrationally or just imperfectly. It can aggregate and accommodate even the flawed behaviour of exuberant capital markets (or middle-class parents searching for a suitable school place, as the case may be) through the price signal.

Hayek is clearly aware of the revelatory aspects of his ideas when he says:

The crucial point is that it is infinitely more difficult rationally to comprehend the necessity of submitting to forces whose operation we cannot follow in detail, than to do so out of the humble awe which religion, or even the respect for the doctrines of economics, did inspire (Hayek, 2006, p. 210). 
Norman's attempt to introduce a Hayekian notion of the market into a Burkean schema as an institution was an attempt to resolve the tension between liberal theories focused on the individual and older conservative thought concerned with collectivities. Norman began by arguing that institutions should be considered to include not only concrete institutions, like rugby clubs or the Women's Institute, but also 'abstract' institutions like the nation state, marriage or the rule of law. Superficially, this seems like a logical proposition, but it is inadmissible for several reasons related to Hayek's 'big' conception of the market.

Hayekian market theory removes the capacity of individuals to produce universal rational outcomes through planning but replaces this with the market as a totality unified through its ability to aggregate a potentially limitless number of price signals. This process of aggregation by the unconscious rationality of the market approximates the decisions which an omniscient consciousness would make, if it existed. Hayek's market therefore differs from Norman's other abstract institutions because of its universal structuring function. The market becomes an abstract universality with particular manifestations (a Market-in-the-world, so to speak). This is made explicit in Hayek's claim that 'the whole acts as one market' (Hayek, 1945, p. 526).

To clarify this point, it is worth briefly digressing to explain why Adam Smith's (and Edmund Burke's) markets could be accommodated within this schema. Even by the time of Smith, markets had ceased to be thought of as purely concrete places of exchange, demonstrated very early in The Wealth of Nations:

As it is the power of exchanging that gives occasion to the division of labour, so the extent of this division must always be limited by the extent of that power, or, in other words, by the extent of the market (Smith, 2008, p. 27).

But Smith also quite clearly saw markets as embedded phenomena within contingent places, describing towns as 'a continual fair or market, to which the inhabitants of the country resort, in order to exchange their rude for manufactured produce'. Burke makes a very similar observation: '[m]arket is the meeting and conference of the consumer and producer, when they mutually discover each other's wants' (Burke, 1999, p. 77). 
In this respect, Smith's market could be considered an abstract institution in Norman's sense, since although the market is an abstract form of exchange, it is also rooted in contingent places (much like marriage or law). Smith has moved from the contingent existence of markets and fairs in towns and cities to an abstraction in which the market stands for all trade. Contra Hayek, however, he does not assert the market as a source of rationality or social order. For Smith, the whole is not one market.

This resembles the nation state, marriage and the rule of law: Norman's other abstract institutions. These are contingent structures which are universalized as ideal types. States preceded the establishment of an abstract idea of the nation state; cohabiting couples existed before a universal institution of marriage; customary laws and rights pre-existed the modern Rechtstaat. Hayekian market theory, on the other hand, does precisely the reverse. Hayek's market is a state of transcendental Reason, which is not realizable in the functioning of concrete markets. Although Norman attempts to mitigate this by arguing that 'markets are culturally created and sustained' and that they are 'a source, not of social breakdown, but of social cohesion' due to their capacity to 'put people in touch with one another' (Norman, 2010, pp. 166-167), there is little theoretical justification of how this relates to Hayek's conception of the market, as such.

This also undermines the Burkean framework of the 'little platoons'. For Burke, there is 'one great master, author and founder of society': God (Burke, 2004, p. 190). The relationships between social institutions therefore far exceed the precarious position of actors in markets:

The municipal corporations of that universal kingdom are not morally at liberty at their pleasure, and to their speculations of a contingent improvement, wholly to separate and tear asunder the bands of their subordinate community and to dissolve into an unsocial, uncivil, unconnected chaos of elementary principles (Burke, 2004, p. 195).

Where Burke did write on the topic of markets, he conceived of them very similarly to Smith (unsurprisingly, since the two were contemporaries and mutual admirers). Burke's primary concern in Thoughts and Details on Scarcity (1999), for example, was to oppose intervention into the wages of agricultural labourers and the price of grain because it risked interfering in 
the balance of private property in rural areas and disturbing the traditional estate-based structure of social organisation (Jameson, 2016, p. 49). If there is an impulse to a theory of the market in Burke therefore, it points in the opposite direction to Hayek's ideas about society organised by the market, presenting instead a market regulated by social considerations about the distribution of property.

This is not to say that any attempt to update the thought of Burke is prima facie doomed to fail. However, to rehabilitate neoliberal economics the mechanism deployed by Norman is clearly a failure. It is not possible to reconcile a tripartite system of the individual, institution and state with a notion of the market so large that it subsumes the institution (and the individual) entirely. Hayek's ontological notion of the market is too conceptually different from institutions in Norman's sense of the term to be accommodated within such logic.

This is made clearer when we return to the price signal. In a Hayekian schema, the market must be the mechanism through which the actions of all other institutional (or individual) actors are aggregated and comprehended as a totality. In that sense alone, the market clearly cannot be an institution like marriage or the family, since the behaviours of concrete families and consumers are systematically conditioned by engagement with it. Theoretically, the distributive logic of the market and the price signal must supersede the logic of institutions which engage with markets or its distributive capacity will cease to function.

Though comprehensive and ambitious, Norman's attempt to rehabilitate neoliberal economics by reading Hayek through Burke must be considered a failure. Fundamentally, this is to do with Norman's own approach to the problem. His assertion of the contingent and plural nature of the institution is at odds with the universalising tendency of the Hayekian market, which infinitely aggregates price signals, theoretically allowing the extension of markets into areas characterised principally by social value.

The reintroduction of the Hayekian market responded to a political need; because of the Thatcher legacy, it would not have been possible for the Conservatives to govern on a platform which even implicitly appeared to reject capitalism or the market. From the perspective of the Conservative Party though, the use of Burke was an expedient, but serious, 
means to reintroduce a sphere for civil society into conservative political theory and to do so without appearing to endorse social democratic ideas about collectivism and corporatism. However, the Party's attempts to do this floundered on the need to keep open a radical notion of free market capitalism.

\section{Conclusion}

The financial crisis of 2008 necessitated a response to the changed economic circumstances confronting British society. The Big Society attempted to offer this through a critique of the economics which it was argued had caused the crash. However, as has been shown, it did this through a disavowal of Chicago School economic theory while at the same time reaffirming and rehabilitating Hayekian market theory. It attempted to marry this to a critique of social breakdown which had been present in the Conservative Party for significantly longer.

This article set out to examine the contours of a distinctively conservative description of neoliberal society; explain and contextualise the accounts of neoliberal failure which were put forward by the Big Society and Red Tory agendas, and analyse why Jesse Norman failed to offer a compelling rehabilitation of neoliberal economics through his attempt to read Hayek through Burke. It made the argument that despite the explicit intention of moving the Conservative Party away from the legacy of Thatcherism, the logic of the Big Society failed to do this because embedded a sphere for markets at the core of its theoretical framework.

Conservative intellectuals began to create an account of neoliberalism with a hard distinction between the Chicago School and the work of Hayek. The latter was perceived as consistent with a more traditional kind of institutional, civic-centred conservatism. However, despite this relatively thoroughgoing critique of homo economicus and the economic model which led to the economic crash, the civic agenda was a failure in its attempt to reorient the Conservative Party away from the 'Thatcher myth'. Moreover, it was argued, the attempt to rehabilitate neoliberal economics by reconciling the traditional conservatism of Burke with Hayek was also unsuccessful.

Norman's attempt to integrate the market into society as institution could not effectively mediate the universalising ontology of Hayekian market theory with the contingent nature of 
even the most 'abstract' institutions like marriage and the rule of law. I concluded that the competing ontologies used by Burke and Hayek cannot be reconciled. Big Society and Red Toryism present a theoretical impasse which neatly reflects the political impasse of the contemporary British right. The inability to theorise and effectively move on from the 2008 global financial crisis is a feature of the requirement that all of this be carried out as a form of esoteric writing, where the totems of free market philosophers like Hayek must be respected even where they do not offer anything of relevance (if they ever did in an economic, rather than political, sense). Norman and Blond's attempts to rethink institutions and the community were ultimately scuppered by the embedded political requirement that they not be too critical of the kind of neo-Thatcherite, deregulatory agenda to which the Conservative Party retreats when under pressure.

The implications of the institutional critique of British society are, at some level, compelling. However, the coupling of the Big Society with 'austerity' enacts on a socio-economic level the very problem of the split between free market liberalism and paternalistic conservatism which Norman and Blond set out to solve. As has been consistently pointed out by scholars, the implications of a flourishing community-based social agenda point in precisely the opposite direction to the continued extension of the market into society. Therefore, what the failed rehabilitation of neoliberal economics demonstrates is that the Conservative Party and society at large faces a confrontation with capitalism in which we will have to come to terms with the market and re-evaluate what it can and cannot effectively and efficiently organise.

\section{Word Count: 8,106}




\section{Bibliography}

Beckett, A. (2019) '“A zombie party": the deepening crisis of conservatism', The Guardian, 28 May.

Blond, P. (2010) Red Tory: How the Left and Right Have Broken Britain and How We Can Fix It. London: Faber and Faber.

Bronk, R. (2013) 'Hayek and the Wisdom of Prices: a reassessment', Erasmus Journal for Philosophy and Economics, 6(1), pp. 82-107.

Buchanan, J. and Tullock, G. (1999) The Collected Works of James M. Buchanan, Vol 3: The Calculus of Consent. Indianapolis: Liberty Fund.

Burke, E. (1999) Select Works of Edmund Burke Volume 4: Miscellaneous Writings. Edited by F. Canavan. Indianapolis: Liberty Fund.

Burke, E. (2004) Reflections on the Revolution in France. London: Penguin Classics.

Byrne, C., Foster, E. and Kerr, P. (2012) 'Understanding Conservative Modernisation', in Heppell, T. and Seawright, D. (eds) Cameron and the Conservatives. London: Palgrave Macmillan, pp. 16-31.

Cameron, D. (2005) 'In full: Cameron victory speech', BBC News, 6 December. Available at: http://news.bbc.co.uk/1/hi/uk_politics/4504722.stm (Accessed: 12 March 2020).

Cameron, D. (2006) 'Leader's Speech'. Available at: http://www.britishpoliticalspeech.org/speech-archive.htm?speech=314 (Accessed: 13 September 2018).

Conservative Party (2017) 'Forward Together: The Conservative Manifesto'. conservatives.com. Available at: https://s3.eu-west-2.amazonaws.com/conservativeparty-manifestos/Forward+Together+-

+Our+Plan+for+a+Stronger+Britain+and+a+More+Prosperous....pdf.

'The Conservative and Unionist Party Manifesto' (2019). conservatives.com. Available at: https://assets-global.website-

files.com/5da42e2cae7ebd3f8bde353c/5dda924905da587992a064ba_Conservative \%202019\%20Manifesto.pdf.

Corbett, S. and Walker, A. (2012) 'The Big Society: Back to the Future', Political Quarterly, 83(3), pp. 487-493. 
Corbett, S. and Walker, A. (2013) 'The Big Society: Rediscovery of "the social" or rhetorical figleaf for neo-liberalism?', Critical Social Policy, 33(3), pp. 451-472.

Cornelissen, L. (2017) 'The Secularization of Providential Order: F.A. Hayek's PoliticalEconomic Theology', Political Theology, 18(8), pp. 660-676.

Coote, A. (2011) 'Big Society and the New Austerity', in Stott, M. (ed.) The Big Society Challenge. Cardiff: Keystone Development Trust, pp. 80-93.

Dean, M. (2014) 'Rethinking neoliberalism', Journal of Sociology, 50(2), pp. 150-163.

Denver, D. (2012) 'The Conservatives and the Electorate', in Cameron and the Conservatives. London: Palgrave Macmillan, pp. 44-59.

Dommett, K. (2015) 'The Theory and Practice of Party Modernisation: the Conservative Party under David Cameron', British Politics, 10(2), pp. 249-266.

Dorey, P. and Garnett, M. (2012) ‘No such thing as the "Big Society”? The Conservative Party's unnecessary search for "narrative" in the 2010 General Election', British Politics, 7(4), pp. 389-417.

Dowling, E. and Harvie, D. (2014) 'Harnessing the Social: State, Crisis and (Big) Society', Sociology, 48(5), pp. 869-886.

Driver, S. (2011) 'Welfare Reform and Coalition Politics in the Age of Austerity', in Lee, S. and Beech, M. (eds) The Cameron-Clegg Government. Basingstoke: Palgrave Macmillan, pp. 105-117.

Exley, S. and Ball, S. J. (2011) 'Something old, something new... understanding Conservative education policy', in Bochel, H. (ed.) The Conservative Party and Social Policy. Bristol: The Policy Press, pp. 97-117.

Gamble, A. (2012) 'Economic Policy', in Heppell, T. and Seawright, D. (eds) Cameron and the Conservatives: The Transition to Coalition Government. London: Palgrave Macmillan, pp. 59-73.

Gamble, A. (2015) 'The Thatcher myth', British Politics, 10(1), pp. 3-15.

Gibson, H. (2015) 'Between the state and the individual: "Big Society" communitarianism and English Conservative rhetoric', Citizenship, Social and Economics Education, 14(1), pp. 40-55.

Halfon, R. (2012) Stop the Union-Bashing. London: Demos.

Harvie, D. (2019) '(Big) Society and (Market) Discipline: Social Investment and the Financialisation of Social Reproduction', Historical Materialism, 27(1), pp. 92-124. 
Hayek, F. (1945) 'Knowledge in Society', American Economic Review, 35(4), pp. 519-530.

Hayek, F. (2006) The Road to Serfdom. London: Routledge.

Hayek, F. (2013) Law, Legislation and Liberty. London: Routledge.

Hayton, R. (2016) 'Constructing a new conservatism? Ideology and values', in Peele, G. and Francis, J. G. (eds) David Cameron and Conservative Renewal: The Limits of Modernisation? New Perspectives on the Right. Manchester: Manchester University Press, pp. 41-58.

Heppell, T. (2013) 'Cameron and Liberal Conservatism: Attitudes within the Parmliamentary Conservative Party and Conservative Ministers', British Journal of Politics and International Relations, 14, pp. 340-361.

Heppell, T. (2014) The Tories: from Winston Churchill to David Cameron. London: Bloomsbury. Hickson, K. (2009) 'Conservatism and the poor: Conservative Party attitudes to poverty and inequality since the 1970s', British Politics, 4(3), pp. 341-362.

Jameson, F. (2016) An American Utopia: Dual Power and the Universal Army. Edited by S. Žižek. London: Verso.

Jessop, B. (2015) 'Margaret Thatcher and Thatcherism: Dead but not buried', British Politics, 10(1), pp. 16-30.

Kerr, P. and Hayton, R. (2015) 'Whatever happened to Conservative Party modernisation?', British Politics, 10(2), pp. 114-130.

Kielos, K. (2009) 'Flight of the Swedish bumblebee', Renewal, 117(2), pp. 61-66.

Levitas, R. (2012) 'The Just's Umbrella: Austerity and the Big Society in Coalition policy and beyond', Critical Social Policy, 32(3), pp. 320-342.

Lister, M. (2015) 'Citizens, Doing It for Themselves? The Big Society and Government Through Community', Parliamentary Affairs, 68, pp. 352-370.

Members of the One Nation Caucus (2019) 'One Nation conservatism can make a success of Brexit', The Observer, 18 May. Available at: https://www.theguardian.com/politics/2019/may/18/one-nation-conservativeslaunch-declaration-values.

Norman, J. (2008) Compassionate Economics. London: Policy Exchange.

Norman, J. (2010) The Big Society. Buckingham: University of Buckingham Press.

Norman, J. and Ganesh, J. (2006) Compassionate Conservatism. London: Policy Exchange. 
North, P. (2011) 'Geographies and utopias of Cameron's Big Society', Social \& Cultural Geography, 12(8), pp. 817-827.

Peck, J. (2010) Constructions of Neoliberal Reason. Oxford: Oxford University Press.

Sage, D. (2012) 'A challenge to liberalism? The communitarianism of the Big Society and Blue Labour', Critical Social Policy, 32(3), pp. 365-382.

Smith, A. (2008) Wealth of Nations. Oxford: Oxford University Press.

Smith, M. and Jones, R. (2015) 'From big society to small state: Conservatism and the privatisation of government', British Politics, 10(2), pp. 226-248.

Strauss, L. (1988) Persecution and the Art of Writing. London: University of Chicago Press.

Tam, H. (2011) 'The Big Con: Reframing the state/society debate', Public Policy Research (IPPR), (March-May).

Whyte, J. (2019) 'The Invisible Hand of Friedrich Hayek: Submission and Spontaneous Order', Political Theory, 47(2), pp. 156-184.

Willetts, D. (1992) Modern Conservatism. London: Penguin. 